\title{
The effects of pre-retirement factors and retirement route on circumstances in retirement: findings from the Whitehall II study
}

\author{
MARTIN HYDE*, JANE FERRIE*, PAUL HIGGS $\dagger$, GILL MEIN* \\ and JAMES NAZROO*
}

\begin{abstract}
Retirement has traditionally been seen as the beginning of old age. It has been depicted as mandatory expulsion from the workforce and seen to mark the transition to a period of ill health and poverty. Such ideas and associations are however being challenged in the developed world by socio-demographic changes in retirement and old age. People in the United Kingdom as elsewhere are living longer and healthier lives, and many older people have access to non-state incomes that afford them a reasonable standard of living in retirement. There is however still concern that inequalities persist into old age. Data from two waves of the British Whitehall II study have been used to assess the relative effects of occupational grade, psychological and general health during working life, and retirement patterns or pathways on activities, attitudes to health and income in retirement. The results show that the majority of the sample reported good health, financial security and overall satisfaction with life, but with observable inequalities. Regression analyses demonstrate that pre-retirement circumstances generally had a greater effect on later life than the retirement route or pathway. Retirement no longer represents a drastic break between working and post-work life but rather, the results suggest, there are continuities between the two periods. It is concluded that the main causes of inequalities in retirement are work-based rather than in retirement itself.
\end{abstract}

$\boldsymbol{K E Y} \boldsymbol{W O R D S}$ - pre-retirement circumstances, retirement route, post-retirement circumstances.

\section{Background}

Retirement has traditionally marked the onset of old age (Philipson I990). As such it is often seen as the beginning of the end (Townsend ig63). The

* Department of Epidemiology and Public Health, University College London.

$\uparrow$ Centre for Behavioural and Social Science in Medicine, University College London. 
(British) notion of an 'old age pensioner' illustrates how most people tacitly take the end of working life as synonymous with the end of social life (Cummings and Henry ig6i; Townsend ig8I; Walker ig8I; Estes 200I). In the United Kingdom, however, and throughout the developed world, these associations are being transformed by complex and contradictory interactions between the changing demographic structure and the reorganisation of work in disorganised capitalism (Gilleard and Higgs 2000; Guillemard and Rein I993; Lash and Urry i987; Amin I996; Taylor et al. 2000). On the one hand the population is getting older as people live longer, healthier lives (Hill et al. I999; Scase and Scales 2000), but at the same time companies have been restructuring their workforces so that patterns of labour force exit have become more varied (Atkinson I984; Henkens and Tazelaar I994; Higgs et al. 2003). Older workers are often targeted for layoffs, sometimes with redundancy packages. Although some workers are able to find other employment, most 'bridge' the period between redundancy and becoming eligible for the state pension with various social security benefits. On the other hand, the increased availability of occupational and private pensions and early retirement incentive packages has given many people the option to retire early (Blundell et al. 200I). In the UK, however, access to and income from occupational pensions are differentiated by social class, gender, cohort and occupational position (Gilleard and Higgs 2000; Mein et al. 2000; Marmot and Nazroo 200I).

Not only have the ways in which people retire changed but also the ways of living in retirement are being radically transformed. Indeed, the experience and image of old age as a whole is changing. Many theories of ageing and older age have focused on the negative aspects of growing older, such as ill health and poverty (Coleman and Bond I99o; Gilleard and Higgs 2000; Higgs I999; Phillipson I998). While there is no doubt that certain groups of older people suffer from poor health and poor financial status or both, it is not true that all older people are poor and sick. The people who are retiring today do not have the same characteristics as those who retired 20 or 30 years ago. Retirement is no longer the mass, forced expulsion from working life, and today's retirees, especially the newly retired, are on average wealthier and healthier than their predecessors. Access to non-state incomes has given some older people a comfortable income in retirement (Department of Work and Pensions 2000). The percentage of pensioner families in the lowest household income quintile has fallen from roughly 50 per cent in I979 to just over 20 per cent in 1997 (Hill et al. I999). The image of old age as a period of physical decay and decrepitude is also being questioned (Kirkwood 2002). Despite increasing concerns about the burden of ill health that may result from an 
ageing population, the evidence seems to point in the opposite direction. For example in I980 a 65-year-old man could expect ir.6 years of disability-free life; in I994 this had increased to I3.5 years in the UK. Even amongst the oldest old, improvements are being achieved. A woman aged 85 years in 1980 was expected to have another 2.7 years of disability-free life: in I994 this had increased to 4.o years (Hill et al. I999: Table 4.I).

Increasingly, writers point to the changing forms and diversity of older people's activities as evidence of an emergent 'third age' (Burnett I99I; Laslett i996; Gilleard and Higgs 2000). The most well-known British advocate and analyst of this lifecourse stage was Peter Laslett. In A Fresh Map of Life, he argued that older age should no longer be seen as a residual stage of the lifecourse whose members are preoccupied with decrepitude and death. Instead, he argued that because people are living longer and healthier lives with more disposable retirement income, older age should be seen as the 'crown of life' in which people are free to develop themselves and their interests (Laslett I996). Instead of being a time to withdraw from social life, retirement can often be an opportunity to engage in various leisure and personal activities (Evenson et al. 2002). The growth of the Universities of the Third Age and the increasing numbers of retired people taking foreign holidays (Burnett I99I) are often cited as evidence. Far from being the end of productive lives, retirement can create time and space for older people to engage in various activities that contribute to the overall wellbeing of their community and of society (Hinterlong, Morrow-Howell and Sherraden 200I). Although these ideas have been criticised for privileging the agency of some groups of older people and ignoring the structural constraints that afflict others, they are corrective of the popular stereotype of older people as dependent and inactive (Bury 1995; Midwinter 1992; Scheidt, Humphreys and Yorgason 1999). Developing Laslett's ideas, Gilleard and Higgs (2002) argued that the third age is a cultural, not a personal, phenomenon that arises from the historically unique life trajectory of the current retiring cohort. The combination of increased healthy old age, non-state pensions and a particular life trajectory have created a set of expectations about retirement: new roles are opening up for older people, but the ability to participate in this culture and to adopt these new roles varies by social position.

As in most sectors, retirement from the civil service over recent decades has taken place alongside a steadily decreasing workforce. Privatisation of many of the functions of civil service departments has reduced the numbers of older and younger workers, and increased job insecurity and health inequalities in the workforce (Ferrie et al. 1998, 2003). As Figure I shows, the periods of high transfers to the private sector generally corresponded with relatively numerous voluntary early retirements. It is important to note 


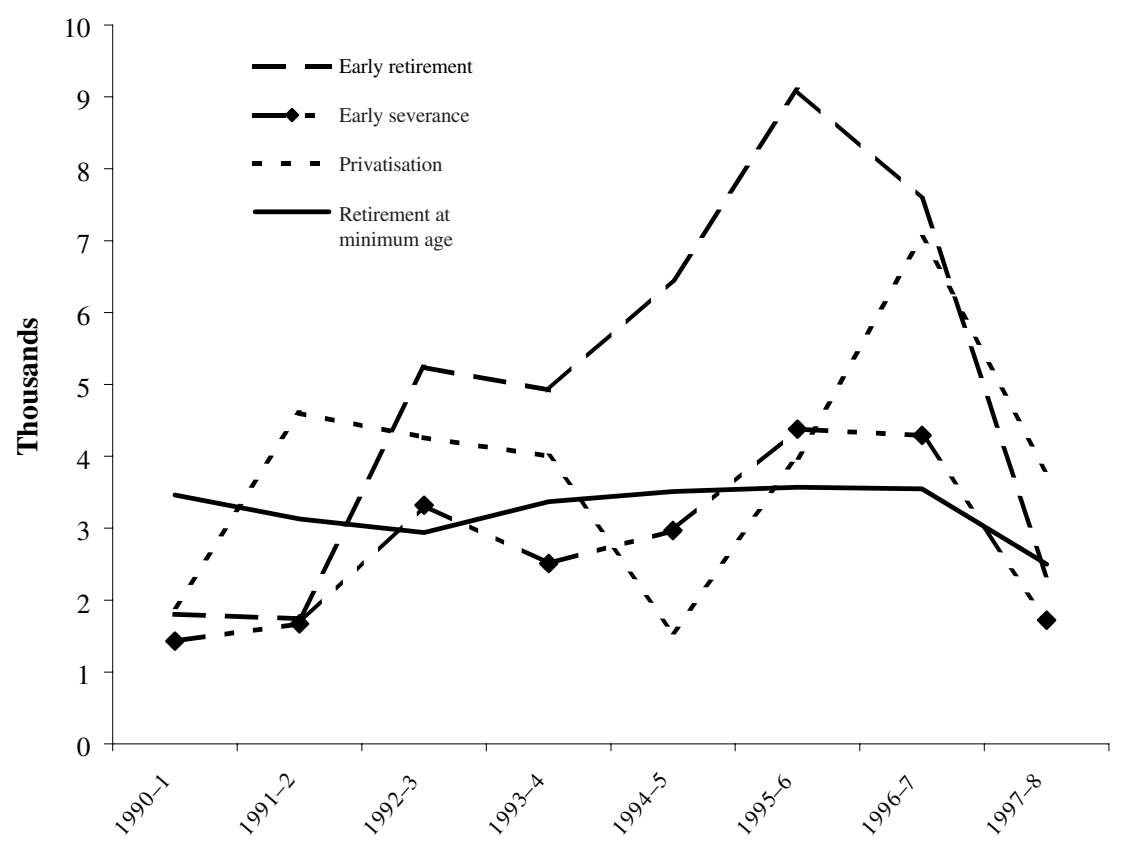

Source: Civil Service Statistics 1998, Table 7, p. 45.

Figure I. Numbers of leavers from the UK civil service during the I99os by selected route (non industrial staff).

that the increase in early labour-market exit has not been a secular trend but rather contingent on several political and economic changes. The 'choice' of early retirement in these conditions might express a desire not to be transferred to the private sector. In a parallel qualitative study, Higgs et al. (2003) found that several respondents cited organisational change as a prime reason for their early retirement from the civil service. Since I998 there has been a fall in the number of civil servants taking voluntary early retirement. As rates decline, the motivations for taking voluntary early retirement and the groups who take voluntary early retirement may change, which might lead to different effects on post-retirement circumstances.

\section{The retirement study}

This paper has three purposes: to detail the characteristics of our sample of retired civil servants; to examine the effects of different routes of labour

\section{CAMBRIDGe JOURNALS}


T A B L E I. Numbers who took different routes out of the civil service and mean ages at Phase 5 (1998-9)

\begin{tabular}{lrc}
\hline & Number & $\begin{array}{c}\text { Mean age } \\
\text { (years) }\end{array}$ \\
\hline Retirement at 6o years of age & $94 \mathrm{I}$ & $64 . \mathrm{I}$ \\
Voluntary early retirement & $\mathrm{I} 586$ & $59 \cdot 0$ \\
Retirement on health grounds & 449 & 58.4 \\
Voluntary redundancy & 426 & 54.8 \\
Total & 3,402 & 59.8 \\
\hline
\end{tabular}

market exit and working status before retirement on the health, social life and financial status of retirees; and to examine the effects of health before retirement, occupational grade and gender on the health, social life and financial status of retirees. The data have been drawn from the Whitehall II study of civil servants which was set up in ${ }_{1985}$ (Phase I) to investigate the degree and causes of health inequalities amongst a working white-collar population.

\section{The sample}

All working civil servants aged $35^{-55}$ years in 20 London-based departments were sent an introductory letter and an initial screening questionnaire. There were I0,308 Phase I respondents, 73 per cent of the selected sample. ${ }^{1}$ Those who agreed to take part and were eligible completed a questionnaire and were given a medical examination which included health measures such as blood pressure and blood cholesterol. At Phase 5 (1998-9), the respondents were sent a questionnaire (identical to that used at Phase 3: $199 \mathrm{I}^{-3}$ ) and received a repeat medical examination. Most of the original sample had by then retired and their characteristics can be searched for predictors of retirement (Mein et al. 2000) and to explore different ideal types of retirement (Higgs et al. 2003). The data used for the analyses reported in this paper were collected at Phase 5, which had a sample of 7,830 , of whom $4,25^{8}$ no longer worked for the civil service, although not all were retired. They were asked by which route they had left the civil service. The sample therefore comprises people who retired at 60 years of age (the mandatory civil service retirement age), with people who took voluntary early retirement or retired on health grounds and accepted voluntary redundancy. The final sample size was 3,402 with a mean age of 59.8 years (standard deviation 5.I years). Table I gives the number of people in each group and their mean ages.

\section{CAMBridge}




\section{Definitions of variables}

Several health, wealth and social variables were chosen as measures of post-retirement circumstances. Physical health was measured using the Activities of Daily Living (ADL) scale (Katz et al. ig63). Scores on these items were summed to create a continuous scale (a high score indicating good physical health). Psychological health was measured using the General Health Questionnaire (GHQ30) (Banks I983). Scores on these items were summed to create a continuous variable (a high score indicating poor mental health). Financial status was measured using annual personal income and the self-estimated value of household assets. Each of these was used as a continuous variable. The Phase 5 questionnaire contained a special section on retirement and pre-retirement, with nine questions on people's attitudes and others on activities in retirement. The nine attitude scores were recoded and summed to create a continuous scale (' 0 ' indicates pessimism about retirement and ' 9 ' optimism). ${ }^{2}$ The respondents were asked if in their spare time they pursued I 3 activities, such as taking an educational course, going to the cinema, and do-it-yourself home improvements. Scores for these items were summed to create a continuous variable ('o' indicating that they did none).

Measures of pre-retirement circumstances and retirement pathways were taken from the Phase 3/5 questionnaire. Last-known occupational grade was allocated to one of three groups: high (positions such as permanent secretary and principal medical officer), middle (e.g. patent examiner and architect), and low (e.g. office assistant and messenger). Dummy variables were created both for the different retirement pathways and for last-known grade. The self-rated GHQ question at Phase 3 was used as a measure of physical health before retirement. This was transformed into a binary variable with 'better' (combining 'excellent' and 'very good') and 'worse' (combining 'good', 'poor' and 'very poor') classes, and was used as a dummy variable. The GHQ-3o score at Phase 3 was also used to control for the influence of earlier psychological health status on circumstances in retirement. Age and sex were included.

Three multiple linear regression models were calibrated to examine the relative influence of pre-retirement circumstances and retirement patterns on circumstances in retirement. Model I solely comprised the different retirement pathways, whereas health before retirement, sex and age were added in the second model, and last-known occupational grade was introduced into the third model. The successive models explored the relative causal effects of demographic characteristics, pre-retirement circumstances and retirement pattern on post-retirement circumstances. The standardised beta coefficients are reported. 
T A B L E 2. Selected characteristics of the sample

\begin{tabular}{|c|c|c|c|}
\hline & $\%$ & & $\%$ \\
\hline Marital status & & Personal annual income $(£ \mathrm{k})$ & \\
\hline Married/cohabiting & 77.0 & $<\mathrm{IO}$ & 26.8 \\
\hline Widowed & I 2.4 & IO-I 4.9 & $25 \cdot 5$ \\
\hline Divorced & 6.3 & I5-19.9 & I6.9 \\
\hline Separated & 4.2 & $20-24.9$ & I2.8 \\
\hline Financial security & & $25-34 \cdot 9$ & Io.8 \\
\hline Secure & $34 \cdot \mathrm{I}$ & $35-49 \cdot 9$ & $4 \cdot \mathrm{I}$ \\
\hline Fairly secure & 57.0 & $50+$ & $3 \cdot 2$ \\
\hline Fairly insecure & 6.3 & Satisfaction with life & \\
\hline Insecure & 2.6 & Very dissatisfied & I.9 \\
\hline General health & & Moderately dissatisfied & 3.6 \\
\hline Excellent & Іі. 6 & A little dissatisfied & 6.6 \\
\hline Very good & $3^{8.1}$ & No feelings either way & 3.2 \\
\hline Good & $35 \cdot 6$ & A little satisfied & 4.9 \\
\hline Fair & I2.5 & Moderately satisfied & 46.3 \\
\hline Poor & 2.2 & Very satisfied & $33 \cdot 2$ \\
\hline \multicolumn{4}{|l|}{ Household assets ( $(\mathrm{k})$} \\
\hline$<5$ & 2.4 & & \\
\hline $5-9 \cdot 9$ & I. 8 & & \\
\hline IO -39.9 & $4 \cdot 3$ & & \\
\hline $4^{0-99 \cdot 9}$ & I5.7 & & \\
\hline IOO- $499 \cdot 9$ & 67.8 & & \\
\hline $500+$ & 8.2 & & \\
\hline
\end{tabular}

Note: 67.9 per cent of the sample were men, and 32. i per cent were women.

\section{Results}

\section{Characteristics of the sample}

Table 2 shows that men outnumbered women by around two-to-one in the sample. The marital status of the sample was similar to that of the general population aged 50-69 years in Great Britain (Hill et al. 1999). The overwhelming majority $(77 \%)$ of the sample and the age group were married or cohabiting. Around 85 per cent of the respondents reported being satisfied with their lives, and the majority reported excellent (I2\%), very good $(38.1 \%)$ or good $(35.6 \%)$ health, and very few $(2.2 \%)$ poor health. Just over a quarter of the sample had a personal annual income of under $£ 9,999$, and around one half received under $\mathcal{E}_{\mathrm{I}} 4,999$ a year. Eighteen per cent received more than $£ 25$, 000 a year (including 3.5\% who received over $\left.£ 5^{0}, 000\right)$. The overwhelming majority of the sample $(67.8 \%)$ estimated their assets to be between $£$ Ioo,ooo and half-a-million pounds. Over go per cent of the sample reported feeling financially secure. Table 3 cross-tabulates last-known grade with sex and retirement pattern. Those from the highest grade were much more likely to take early

\section{CAMBRIDge JOURNALS}


T A B L E 3. Retirement pathways by former civil service grade and sex

\begin{tabular}{|c|c|c|c|c|c|c|c|c|c|c|}
\hline & \multicolumn{6}{|c|}{ Civil service grade ${ }^{1}$} & \multicolumn{4}{|c|}{ Sex of respondent $t^{2}$} \\
\hline & \multicolumn{2}{|c|}{ Highest } & \multicolumn{2}{|c|}{ Middle } & \multicolumn{2}{|c|}{ Lowest } & \multicolumn{2}{|c|}{ Men } & \multicolumn{2}{|c|}{ Women } \\
\hline & $\mathrm{N}$ & $\%$ & $\mathrm{~N}$ & $\%$ & $\mathrm{~N}$ & $\%$ & $\mathrm{~N}$ & $\%$ & $\mathrm{~N}$ & $\%$ \\
\hline Retirement at 60 & 359 & 25.8 & $3^{89}$ & 26.3 & 185 & 35.9 & 603 & 26.2 & $33^{8}$ & 30.7 \\
\hline Voluntary early retirem & 728 & $5^{2} \cdot 3$ & 690 & $4^{6.7}$ & 162 & $3^{1.5}$ & II 33 & 49.2 & 453 & $4 \mathrm{I} .2$ \\
\hline Retirement on health grounds & 95 & 6.8 & 2 II & I $4 \cdot 3$ & I 40 & 27.2 & 245 & Iо. 6 & 204 & I8.6 \\
\hline Voluntary redundancy & 210 & I5.I & 187 & I2.7 & 28 & $5 \cdot 4$ & $3^{2 I}$ & I 3.9 & I05 & $9 \cdot 6$ \\
\hline Total & I 392 & IOO & I477 & 100 & 515 & 100 & 2302 & 100 & IIOO & IOO \\
\hline
\end{tabular}

Significance levels: I. $p=<$ o.00I ( 6 degrees of freedom). 2. $p=<$ o.0oI (3 degrees of freedom).

retirement, whilst those from the lowest grade the least likely. This pattern was reversed among those who retired on health grounds. Almost onethird of the lowest grade retired due to poor health, compared to seven and 14 per cent respectively of the top and middle grades. Chi-squared analysis revealed a significant relation between grade and retirement pattern $(p<$ o.ooI). Men were slightly less likely to retire at 60 years of age $(27 \%)$ or because of ill health (II \%) than women $(30 \%$ and I8 \% respectively), but women were slightly less likely to take early retirement (4I \%) or compulsory retirement (I0 \%) than men ( $49 \%$ and $\mathrm{I} 4 \%$ respectively). There was a significant relation between sex and retirement pattern $(p<$ o.oOI $)$.

\section{Attitude to retirement and activities in retirement}

Table 4 shows the results of three regression models for both 'attitudes to retirement' and 'retirement activities'. In both cases, model i examines the influence of only the retirement pattern, model 2 adds health, age and sex, while model 3 adds the civil service grade. Both voluntary early retirement and retiring on health grounds had a significant effect on attitudes to retirement (positively and negatively respectively). When health before retirement was included, however, the effect of retiring on health grounds was no longer significant. Occupational grade before retirement had no significant effect on attitudes to retirement.

Turning to the associations with the number of retirement activities, in model I voluntary early retirement had a significant positive effect and retiring on health grounds had a significant negative effect. In model 2, however, voluntary early retirement had none, although better general health before retirement and being male both had significant positive effects, whilst psychological distress before retirement had a strong negative effect. Retiring on health grounds retained a significant, albeit smaller, 
T A B L E 4. Regression models for 'attitude to retirement' and 'participation in activities'

\begin{tabular}{|c|c|c|c|c|c|c|}
\hline & \multicolumn{3}{|c|}{ Attitude to retirement } & \multicolumn{3}{|c|}{ Participation in activities } \\
\hline & & $\beta$ & & & $\beta$ & \\
\hline & Model I & Model 2 & Model $_{3}$ & Model I & Model 2 & Model 3 \\
\hline $\begin{array}{l}\text { Retirement pattern } \\
\text { Retired at } 60 \text { years } \\
\text { Voluntary early retirement } \\
\text { Retired on health grounds } \\
\text { Voluntary redundancy }\end{array}$ & $\begin{array}{c}0.057^{*} \\
-0.102^{* *} \\
0.033\end{array}$ & $\begin{array}{c}0.055^{*} \\
-0.024 \\
0.030\end{array}$ & $\begin{array}{r}0.055^{*} \\
-0.023 \\
0.030\end{array}$ & $\begin{array}{c}0.055^{*} \\
-0.137^{* *} \\
0.03^{2}\end{array}$ & $\begin{array}{c}0.04 \mathrm{I} \\
-0.096^{* *} \\
0.018\end{array}$ & $\begin{array}{c}\text { o.018 } \\
-0.080^{*} \\
-0.006\end{array}$ \\
\hline $\begin{array}{l}\text { Health } \\
\text { Worse general health at } \\
\text { Phase } 3 \\
\text { Better general health at } \\
\text { Phase } 3 \\
\text { GHQ at Phase } 3\end{array}$ & & $\begin{array}{r}0.08 \mathrm{I}^{* *} \\
-0.243^{* *}\end{array}$ & $\begin{array}{c}0.080^{* *} \\
-0.243^{* *}\end{array}$ & & $\begin{array}{r}0.059^{*} \\
-0.057^{*}\end{array}$ & $\begin{array}{c}0.037 \\
-0.054^{*}\end{array}$ \\
\hline Age & & -0.024 & -0.024 & & -0.016 & - -.ого \\
\hline $\begin{array}{l}\text { Sex } \\
\text { Female } \\
\text { Male }\end{array}$ & & 0.014 & 0.013 & & $0.185^{* *}$ & $0.043^{*}$ \\
\hline $\begin{array}{l}\text { Status } \\
\text { Highest grade } \\
\text { Middle grade } \\
\text { Lowest grade }\end{array}$ & & & $\begin{array}{r}0.003 \\
-0.004\end{array}$ & & & $\begin{array}{l}-0.208^{* *} \\
-0.330^{\text {*** }}\end{array}$ \\
\hline Explained variance $\left(R^{2}\right)$ & o.o19 & 0.090 & 0.090 & 0.028 & 0.072 & 0.153 \\
\hline
\end{tabular}

Significance levels: $* p=<0.005, * * p=<0.00 \mathrm{I}$.

effect even when these health measures were included. Model 3 shows that coming from the lower grades also had a significant negative effect on the number of retirement activities. The grade also appears to account for some of the effect of self-rated health before retirement, for its effect was insignificant in the model 3 . The overall explained variance $\left(R^{2}\right)$ of the two final models was quite small, at nine per cent for attitudes to retirement and $\mathrm{I} 5$ per cent for retirement activities.

\section{Physical and mental health}

Table 5 shows the results of the three regression models for physical and mental health in retirement. In the first model all the retirement patterns had a significant effect on physical health. Voluntary early retirement and voluntary redundancy had a positive effect whilst retiring on health grounds had a negative effect. With the inclusion of pre-retirement health and demographic variables in the second model, the influence of voluntary redundancy became insignificant. Better general health and good

\section{CAMBRIDGE JOURNALS}


T A в L E 5. Regression models for physical and mental health

\begin{tabular}{|c|c|c|c|c|c|c|}
\hline & \multicolumn{3}{|c|}{ ADL at Phase 5} & \multicolumn{3}{|c|}{ GHQ at Phase 5} \\
\hline & \multicolumn{3}{|c|}{$\beta$} & \multicolumn{3}{|c|}{$\beta$} \\
\hline & Model I & Model 2 & Model 3 & Model I & Model 2 & Model 3 \\
\hline \multicolumn{7}{|l|}{ Retirement pattern } \\
\hline Voluntary early retirement & $0.123^{* *}$ & $0.045^{*}$ & 0.034 & 0.007 & -0.010 & -0.005 \\
\hline Retired on health grounds & $-0.306^{* *}$ & $-0.248^{* *}$ & $-0.23^{* * *}$ & $0.243^{* *}$ & $0.117^{* *}$ & $0.112 * *$ \\
\hline Voluntary redundancy & $0.105^{* *}$ & 0.017 & 0.008 & 0.036 & 0.014 & 0.018 \\
\hline \multicolumn{7}{|l|}{ Health } \\
\hline \multicolumn{7}{|l|}{$\begin{array}{l}\text { Worse general health at } \\
\text { Phase } 3\end{array}$} \\
\hline $\begin{array}{l}\text { Better general health at } \\
\text { Phase } 3\end{array}$ & & $0.203^{* *}$ & o.192** & & $-0.085^{* *}$ & $-0.079^{* *}$ \\
\hline GHQ at Phase 3 & & $-0.093^{* *}$ & $-0.092^{* *}$ & & $0.401^{* *}$ & $0.400^{* *}$ \\
\hline Age & & $-0.133^{* *}$ & $-0.126^{* *}$ & & 0.004 & 0.000 \\
\hline \multicolumn{7}{|l|}{ Sex } \\
\hline \multicolumn{7}{|l|}{ Female } \\
\hline Male & & $0.253^{* *}$ & $0.185^{* *}$ & & $-0.087^{* *}$ & $-0.055^{*}$ \\
\hline \multicolumn{7}{|l|}{ Status } \\
\hline \multicolumn{7}{|l|}{ Highest grade } \\
\hline Middle grade & & & $-0.060^{* * *}$ & & & 0.028 \\
\hline Lowest grade & & & $-0.16 \mathrm{I}^{* *}$ & & & $0.075^{* *}$ \\
\hline Explained variance $\left(R^{2}\right)$ & o.I 45 & 0.277 & 0.294 & 0.057 & 0.245 & 0.248 \\
\hline
\end{tabular}

Significance levels: $* p=<0.005, * * p=<0.001$.

mental health before retirement as well as being male had positive effects on physical health in retirement, whilst being older had a negative effect. These effects were relatively unchanged with the inclusion of grade in the third model, in which the effect of voluntary early retirement diminished and became insignificant. The third model also shows that coming from the lower grades had a significant negative effect on physical health in retirement. Retiring on health grounds was the only retirement pattern that had a significant effect on mental health in retirement. It retained its significance despite the inclusion of health before retirement, although the strength of the effect more than halved. Unsurprisingly, mental health before retirement had the strongest and most robust effect, and lost hardly any strength in the third model with the introduction of grade. Better general health before retirement and being male also had positive effects on mental health in retirement, whilst coming from the lowest grade had a negative effect. The third model explained 29 and 25 per cent respectively of the variance $\left(R^{2}\right)$ in physical and psychological health after retirement.

\section{CAMBridge}


T А в L E 6. Regression models for 'personal income' and 'household assets'

\begin{tabular}{|c|c|c|c|c|c|c|}
\hline & \multicolumn{3}{|c|}{ Personal annual income } & \multicolumn{3}{|c|}{ Household assets } \\
\hline & & $\beta$ & & & $\beta$ & \\
\hline & Model I & Model 2 & Model 3 & Model I & Model 2 & Model 3 \\
\hline $\begin{array}{l}\text { Retirement pattern } \\
\text { Retired at 6o } \\
\text { Voluntary early retirement } \\
\text { Retired on health grounds } \\
\text { Voluntary redundancy }\end{array}$ & $\begin{array}{r}0.116^{* *} \\
-0.096^{* *} \\
\text { o.136 }\end{array}$ & $\begin{array}{c}0.084^{* *} \\
-0.04 \mathrm{I} \\
{ }^{0.103} 3^{* *}\end{array}$ & $\begin{array}{c}0.042^{*} \\
-0.016 \\
0.058^{*}\end{array}$ & $\begin{array}{c}0.043^{*} \\
-0.163^{* *} \\
0.025\end{array}$ & $\begin{array}{c}0.04 \mathrm{I} \\
-0.082^{* *} \\
0.028\end{array}$ & $\begin{array}{c}\text { 0.0II } \\
-0.055^{*} \\
\text { o.00I }\end{array}$ \\
\hline $\begin{array}{l}\text { Health } \\
\text { Worse general health at } \\
\text { Phase } 3 \\
\text { Better general health at } \\
\text { Phase } 3 \\
\text { GHQ at Phase } 3\end{array}$ & & $\begin{array}{l}0.07 \mathrm{I}^{* *} \\
-0.033\end{array}$ & $\begin{array}{c}0.029^{*} \\
-0.022\end{array}$ & & $\begin{array}{c}0.120^{* *} \\
-0.07 \mathrm{I}^{* *}\end{array}$ & $\begin{array}{c}0.085^{* *} \\
-0.062^{* *}\end{array}$ \\
\hline Age & & -0.019 & -0.030 & & 0.022 & 0.038 \\
\hline $\begin{array}{l}\text { Sex } \\
\quad \text { Female } \\
\text { Male }\end{array}$ & & $0.35^{* * *}$ & $0.139^{* *}$ & & $0.225^{* *}$ & $0.040^{*}$ \\
\hline $\begin{array}{l}\text { Status } \\
\text { Highest grade } \\
\text { Middle grade } \\
\text { Lowest grade }\end{array}$ & & & $\begin{array}{l}-0.550^{* *} \\
-0.479^{* *}\end{array}$ & & & $\begin{array}{l}-0.226^{* *} \\
-0.450^{* *}\end{array}$ \\
\hline Explained variance $\left(R^{2}\right)$ & $0.04 \mathrm{I}$ & 0.179 & 0.468 & 0.034 & 0.113 & 0.257 \\
\hline
\end{tabular}

Significance levels: $* p=<0.005, * * p=<0.001$.

\section{Financial situation}

Table 6 shows the results of the regression models for annual personal income and estimated household assets. In the first model all the retirement patterns have a significant effect on personal annual retirement income. Both voluntary early retirement and taking voluntary redundancy had positive effects, whilst retiring on health grounds had a negative effect. When health measures were included in the second model, however, only voluntary early retirement and taking voluntary redundancy retained significance. Better general health before retirement appears to have accounted for the effect of retiring on health grounds. Being male had a very strong positive effect on income in retirement, but this seems to be partly explained by grade. As the third model shows, coming from the lowest grades had the strongest effect, which was negative, on annual personal income, although voluntary early retirement, taking voluntary redundancy, better general health and being male also sustained significant effects. The picture is almost reversed when the effect of the retirement route or pathway on household assets is examined. Although voluntary

\section{CAMBRIDge JOURNALS}


early retirement was just significant in the first model, neither voluntary early retirement nor taking voluntary redundancy were significant in the others. Retiring on health grounds had a significant effect in all three models (although the additional independent variables progressively weakened the effect). Better general health before retirement and being male both had significant negative effects on household assets. Poor psychological health and coming from the lowest grades had significant, and in the case of the lowest grade very strong, negative effects. The third model explained 25 per cent of the variance $\left(R^{2}\right)$ in reported household assets when retired, and accounted for almost 50 per cent of the variance in personal retirement income.

\section{Discussion and conclusions}

The common pathways into retirement and the meaning of retirement are changing in the United Kingdom (Laczko and Phillipson I99I). The fact that more and more people are leaving work before the state-sponsored retirement age, whether through choice or compulsion, is destabilising the association between retirement and (stereotypical notions of) old age. It has been argued that the improved financial status and health of older people are creating a historically unique cultural space in which older people can pursue diverse experiences (Gilleard and Higgs 2002; Hinterlong, Morrow-Howell and Sherraden 200I; Laslett 1996). Such optimism should however be tempered by recognition of the differentials in access to such experiences by social group (Midwinter i992; Nazroo and Marmot 200I). There is concern that the way in which a person enters retirement might affect his or her ability to participate in the new 'third age' culture and thereby enjoy retirement. The Phase 5 data of the Whitehall II study have supported an examination of the health, financial status and attitudes to retirement of retired British civil servants and of the impact upon them of different retirement patterns.

Although the Whitehall II study was not designed specifically to study retirement, its longitudinal data are well suited to tests of the effects of preretirement circumstances and retirement pathways on post-retirement life. Given the complex relationships between health, occupational status and retirement, it is difficult to address these questions with cross-sectional data, but it is nonetheless important to be aware of the limitations of the sample. The Whitehall II sample was drawn exclusively from white-collar civil servants, whose normal retirement age for both sexes has been at 60 years, whereas in the general population the state pension eligibility ages are 65 years for men and 6o years for women. While it is not possible to

\section{CAmbridge}


generalise for the general population from a white-collar civil service sample, considerable understanding of retirement processes and outcomes has been achieved through the study of a large and heterogeneous occupational group who have been offered the same range of retirement pathways and incentives.

Moreover, information about this sample of generally healthy and financially-secure retirees could help correct the prevailing image of retired people as an undifferentiated, socially-marginalised group characterised by poverty and ill health. Table I suggests that retirement has become deinstitutionalised as patterns of labour market exit become more varied. This was confirmed by the findings of an earlier, qualitative study of British civil servants which identified several 'ideal types' of pathways to early retirement and employment in later life (Higgs et al. 2003). Although it appears that increasing numbers are choosing to retire before the normal retirement age, the data presented in Figure I show a decrease since I997 in voluntary early retirement; it may have been a temporary phenomenon. It is also important to note that retirement on health grounds differs from the other forms of retirement considered here, because it is funded through The Treasury not the individual civil service departments; consequently there are strict eligibility criteria and those deemed eligible tend to be seriously ill.

Nevertheless, the evidence presented in this paper demonstrates the need to re-evaluate the traditional images of and approaches to studying retirement and old age. For certain groups, retirement has ceased to be a negative involuntary event, and there is marked variation in individuals' circumstances. Far from being plagued by ill health, the majority of the sample reported good health, while the financial situation of the sample is equally instructive. While the personal income data confirm that retirement entails a significant reduction in income, the majority of the sample reported substantial household assets. While this may be partly because many of the respondents lived in and around London (and its exceptionally high property values), the finding illustrates the limitations of income as an indicator of the financial situation of older people. As Hardy and Hazelrigg (1999) have noted, older people are much more likely than younger people to have purchased their house (hence, have no mortgage repayments) and to have paid off their debts. This is reflected in the fact that most of the sample reported good financial security. Given their good health and financial position, it is not surprising that the majority reported being satisfied with life.

The relationship between health before retirement and positive and negative attitudes to retirement was expected (not least because half of the questions were about perceptions of health after retirement). Even so, 
those entering retirement with health problems were much less likely to perceive retirement as a period of opportunity. As the findings on activities showed, poor health constrained participation in many activities in later life. Interestingly, though, coming from the lower grades had a greater negative effect than health on the number of activities that were pursued. Those coming from the lower grades may simply not have had the time or money to develop interests or pursuits for retirement, or the relationship may reflect the relative availability of opportunities to engage in activities pre- and post-retirement. It could be that those from the highest civil service grades lived in areas with better leisure facilities or that they had superior access to public or private transport. It is likely, though, that a combination of these privileges created an environment that increased people's propensity to engage in activities.

Whatever the reasons, the findings raise serious questions about the ability or desire of some older people to enjoy the opportunities of the 'new retirement', which, given the contribution of leisure to the quality of life of older people, is a concern (Bosanquet i987; Midwinter 1992; Hogg 1993). The evidence presented in this paper indicates that structural inequalities at work persist into retirement, although the low explanation of the variance in both attitudes to retirement and participation in activities suggests that other, non work-based, factors, such as social networks, are important influences on how people approach retirement.

Unlike those who retire on the grounds of ill health, those who take early retirement are relatively optimistic about retirement. They may be more likely to plan for their retirement and to look forward to doing things that they could not do whilst at work; or it could simply be that they were dissatisfied with work and happy to leave. Qualitative interviews with a sample of British civil servants showed that both these motivations influenced people's decision to take early retirement (Higgs et al. 2003). Whatever the reasons, the independent effect of voluntary early retirement from grade suggests that expectations about retirement are emerging that are not reducible to social class behaviours or preferences.

The results from the analyses of the retirement patterns show that retirement per se does not mark a radical break in health or in the financial situation. Only retiring on the grounds of ill health has an effect on health in retirement. Given the stringent eligibility criteria for retirement on health grounds, those who take it must be judged incapable of work. Health while at work and occupational grade affect both physical and psychological health in retirement. Coming from the lowest grade has a negative impact on physical and psychological health in retirement. This finding corroborates evidence of the effect of grade on health at work (Marmot et al. 200I) and is consistent with the 'accumulation of the

\section{CAMBridge}


hazards' model of the lifecourse approach to health inequalities (Pavalko, Elder and Clipp ı993; Blane et al. 1999; Bartley and Plewis 2002; BenShlomo and Kuh 2002). Health in retirement is, thus, produced by complex interactions between health at work, grade and retirement pathway (Nazroo and Marmot 200I). What these findings suggest is that government and employers should focus efforts on reducing health inequalities at work, through workplace initiatives such as the Health Service Executive's proposed 'Stress Priority Programme', in order to offset poor health in future cohorts of retirees.

Both voluntary early retirement and compulsory redundancy had a positive effect independent of grade on personal annual income in retirement. Although for these analyses we do not know the size of the financial package that people were offered, there is evidence that this has an effect on the decision to take early retirement (Higgs et al. 2003). However, as with post-retirement health, the mechanisms that produce financial circumstances for older people (for both personal income and household assets) are principally pre-retirement. Here gender is a crucial factor. In line with other studies, the results clearly show the effect of gender on the financial situation in older age. As Ginn and Arber (200I) point out, there are many reasons why women receive poorer pensions than men, such as taking career breaks to care for family members and gender segregation at work. As expected, the last known grade has the greatest effect on the financial situation of the sample. Given that the civil service occupational pension is calculated as a percentage of final salary, it is unsurprising that those in the top grades receive better pensions than those in the lower grades.

Thus, although retirement in general and early retirement in particular might be opening up new opportunities for people to engage in a range of activities, the ability to access and enjoy them are structured over the working life. If governments are serious about releasing the potential of the older population and increasing access to a range of activities (DSS 2000), then it is obviously not enough simply to concentrate on those who are already retired. Greater understanding of these mechanisms is required so that effective policies may be enacted throughout the working life. Such policies will help to ensure that all are able to benefit from these historically new opportunities.

\section{Acknowledgements}

The work for this paper was funded by a research grant from The Nuffield Foundation. The Whitehall II was supported by grants from the UK Medical Research Council, British Heart Foundation, Health and Safety Executive, Department of Health, National Heart Lung and Blood Institute (HL363ro), the 
United States National Institute on Aging of the National Institutes of Health (NIH) (AGi3ig6), the US Agency for Health Care Policy Research (NIH) (HSo65I6), and the John D. and Catherine T. MacArthur Foundation Research Networks on 'Successful midlife development' and 'Socio-economic status and health'. We also thank all those who participated in the Whitehall II study and all members of the Whitehall II study team.

\section{NOTES}

I At Phase 2, the response rate was 79 per cent of the Phase I sample; at Phase 3 it was 8I per cent; at Phase 4 it was 84 per cent; and at Phase 5 it was 76 per cent. Those who participated in the original survey were sent self-completion questionnaires in I989 (Phase 2), I99 ${ }^{-3}$ (Phase 3), I995-6 (Phase 4), I998-9 (Phase 5) and 2000 (Phase 6).

2 The items for attitudes to retirement from Phase 5 of the Whitehall II study were: I am looking forward to retirement; I feel apprehensive/unsure about retirement; I have a fear of the unknown; I have no feelings either way; I have mixed feelings about retirement; I dislike change in daily routines; I look forward to the freedom to organise my own time; I have a fear of loneliness; and I shall be relieved to leave my job.

\section{References}

Amin, A. 1996. Post-Fordism: models, fantasies and phantoms of transition. In Amin, A. (ed.), Post Fordism: A Reader. Blackwell, London, I-40.

Atkinson, J. 1984. Manpower strategies for flexible orgainsations. Personnel Management, I 2, 24-39.

Banks, M. H. I983. Validation of the general health questionnaire in a young community sample. Psychological Medicine, I 3, 349-53.

Bartley, M. and Plewis, I. 2002. Accumulated labour market disadvantage and limiting long term illness: data from the 197I-199I Office for National Statistics Longitudinal Study. International Fournal of Epidemiology, 31, 336-4I.

Ben-Shlomo, Y. and Kuh, D. 2002. A lifecourse approach to chronic disease epidemiology conceptual models, empirical challenges and interdisciplinary perspectives. International Fournal of Epidemiology, 31, 285-93.

Blane, D. B., Berney, L. R., Smith, G. D., Gunnel, D. J. and Holland, P. r999. Reconstructing the lifecourse: health during early old age in a follow up study based on the Boyd Orr cohort. Public Health, I I 3, I I7-24.

Blundell, R., Meghir, C. and Smith, S. 200I. Pension Incentives and the Pattern of Retirement. Institute for Fiscal Studies, London.

Bosanquet, N. 1987. A Generation in Limbo: Government, the Economy and the 55-65 Age Group in Britain. Public Policy Centre, London.

Burnett, J. J. I99I. Examining the media habits of the affluent elderly. Fournal of Advertising Research, го, 33-4I.

Burr, J. A., Caro, F. G. and Moorhead, J. 2002. Productive aging and civic participation. Fournal of Aging Studies, r6, 87-I05.

Bury, M. 1995. Ageing, gender and sociological theory. In Arber, S. and Ginn, J. (eds), Connecting Gender and Ageing. Open University Press, Buckingham, I5-30. 
Byrne, D. 2002. Interpreting Quantitative Data. Sage, London.

Cabinet Office. 1998. Civil Service Statistics 1998. Government Statistical Office, London.

Coleman, P. and Bond, J. r99o. Ageing in the 2oth century. In Bond, J. and Coleman, P. (eds), Ageing in Society: An Introduction to Social Gernontology. Sage, London, I-I6.

Cummings, E. and Henry, W. E. I96r. Growing Old: The Process of Disengagement. Basic, New York.

Department of Work and Pensions. 2000. Pensioner Income Series 1999/2000. Her Majesty's Stationery Office, London.

Department of Social Security. 2000. Life Begins at 50: A Better Society for Older People. Department of Social Security, London.

Estes, C. 200r. Social Policy and Aging: A Critical Perspective. Sage, London.

Evenson, K. R., Rosamond, W. D., Jianwen, C., Diez-Roux, A. V. and Brancati, F. L. 2002. Influence of retirement and leisure time physical activity: the atherosclerosis risk in community study. American Fournal of Epidemiology, I 55, 692-9.

Ferrie, J. E., Shipley, M.J., Marmot, M. G., Stansfield, S. and Smith, G. D. I998. The health effects of major organisational change and job insecurity. Social Science and Medicine, 46, 243-54.

Ferrie, J. E., Shipley, M. J., Stansfield, S., Smith, G. D. and Marmot, M. G. 2003. Future uncertainty and socioeconomic inequalities in health: the Whitehall II study. Social Science and Medicine, 57, 637-46.

Gilleard, C. and Higgs, P. 200o. Cultures of Ageing: Self, Citizen and the Body. Prentice Hall, London.

Gilleard, C. and Higgs, P. 2002. The third age: class, cohort or generation? Ageing \& Society, 22, 369-82.

Ginn, J. and Arber, S. 2001. Pension prospects of minority groups: inequalities by gender and ethnicity. British Fournal of Sociology, 52, 519-39.

Guillemard, A. M. and Rein, M. 1993. Comparative patterns of retirement: recent trends in developed societies. Annual Review of Sociology, 1 9, 469-503.

Hardy, M. A. and Hazelrigg, L. E. I999. Fuelling the politics of old age: on economic hardship across the lifecourse. Comment on Mirowsky and Ross. American Sociological Review, 64, 570-6.

Henkens, K. and Tazelaar, F. 1994. Early retirement decisions of civil servants in The Netherlands. Fournal of Applied Social Psychology, 24, I927-43.

Higgs, P. 1999. Quality of life in older age. Aging and Mental Health, 3, I97-8.

Higgs, P., Mein, G., Ferrie, J., Hyde, M. and Nazroo, J. 2003. Pathways to early retirement: structure and agency in decision-making among British civil servants. Ageing $\mathbb{E}^{2}$ Society, 23, 76I-78.

Hill, L., Edwards, G., Myers, L., Saeed, Z., Dunn, S. and Fisher, K. I999. Social Focus on Older People. Stationery Office, London.

Hinterlong, J., Morrow-Howell, N. and Sherraden, M. 200ı. Productive aging: principles and perspectives. In Morrow-Howell, N., Hinterlong, J. and Sherraden, M. (eds), Productive Aging: Concepts and Challenges. Johns Hopkins University Press, Baltimore, 3-19.

Hogg, J. 1993. Creative, personal and social engagement in the later years: realisation through leisure. Irish fournal of Psychology, I4, 208-18.

Katz, S., Ford, A. B. and Moskowitz, R. W. I963. Studies in illness in the aged: the index of $\mathrm{ADL}$ - a standardised measure of biological and psychosocial function. Fournal of the American Medical Association, 185, 914-19.

Kirkwood, T. 2002. The End of Age. Profile, London.

Laslett, P. I996. A Fresh Map of Life. Macmillan, London.

Lash, S. and Urry, J. 1987. The End of Organised Capitalism. Polity, Cambridge.

Laczko, F. and Phillipson, C. I991. Changing Work and Retirement. Open University Press, Buckingham. 
Marmot, M., Shipley, M., Brunner, E. and Hemingway, H. 200I. Relative contribution of early life and adult socioeconomic factors to adult morbidity in the Whitehall II study. Fournal of Epidemiology and Community Health, 55, 30I-7.

Marmot, M. G. and Nazroo, J. Y. 200I. Social inequalities in health in an ageing population. European Reviere, 9, 445-6o.

Mein, G., Martikainen, P., Stansfeld, S. A., Brunner, E. J., Fuhrer, R. and Marmot, M. G. 2000. Predictors of early retirement in British civil servants. Age and Ageing, 29, 529-36.

Midwinter, E. 1992. Leisure: New Opportunities in the Third Age. Report for the Carnegie Inquiry into the Third Age, Carnegie United Kingdom Trust, Dunfermline, Fife, Scotland.

Nazroo, J. Y. and Marmot, M. G. 200I. Health and social welfare implications of an ageing population: what are the uncertainties? In Boeri, T., Börsch-Supan, A., Brugiavini, A., Disney, R., Kapteyn, A. and Peracchi, F. (eds), Pensions: More Information, Less Ideology. Kluwer, Dordrecht, The Netherlands, $137-52$.

Pavalko, E. K., Elder, G. H. and Clipp, E. C. I993. Worklives and longevity: insights from a lifecourse perspective. Fournal of Health and Social Behaviour, 34, 363-80.

Phillipson, C. I990. The sociology of retirement. In Bond, J. and Coleman, P. (eds), Ageing in Society: An Introduction to Social Gerontology. Sage, London, I44-6o.

Phillipson, C. 1998. Reconstructing Old Age: New Agendas in Social Theory and Practice. Sage, London.

Scase, R. and Scales, J. 200o. Fit and Fifty: Employment, Lifestyles, Health, Attitudes, Incomes. Economic and Social Research Council, Swindon, Wiltshire.

Scheidt, R. J., Humphreys, D. R. and Yorgason, J. B. I999. Successful aging: what's not to like? Journal of Applied Gerontology, $\mathbf{1 8}, 277-82$.

Taylor, P., Tillsley, C., Beausoleil, J., Wilson, R. and Walker, A. 200o. Factors Affecting Retirement. Department for Education and Employment, London.

Townsend, P. I963. The Family Life of Older People. Pelican, London.

Townsend, P. I98I. The structured dependency of the elderly: a creation of social policy in the twentieth century. Ageing \& Society, I, 5-18.

Walker, A. I98I. Towards a political economy of old age. Ageing $\mathcal{E}$ Society, I, 73-94.

Address for correspondence:

Accepted I6 October 2003

Martin Hyde, Department of Epidemiology and Public Health, I-I9 Torrington Place, University College, London WGiE 6BT.

e-mail:martinh@public-health.ucl.ac.uk 